\title{
HAST による加速劣化試験
}

\author{
中村 和裕*
}

\section{Evaluation of Accelerated Life Testing by HAST}

\author{
Kazuhiro NAKAMURA*
}

* 新光電気工業株式会社基盤技術研究所（３３81-0103 長野県長野市若穂川田 1457-1）

* Core Technology Research Laboratory, Shinko Electric Industries Co., Ltd. (1457-1 Wakaho Kawada, Nagano-shi, Nagano 381-0103)

\section{1.はじめに}

電子機器関連の加速性を伴う耐湿性評価の 1 つに HAST (Highly Accelerated Temperature and Humidity Stress Test) があり，よく利用されている。これは，もともと半導体デ バイスの加速試験として開発された試験法の1つである。 しかし，プリント配線板などでは，高機能化と環境保全に よる鉛フリーおよびハロゲンフリー化に伴い電子絶縁材料 のグレードアップが進み, 比較的低加速ストレスの温湿度 定常試験（例えば， $85^{\circ} \mathrm{C} 85 \% \mathrm{RH}$ など）では長期試験が必 要となり, その改善策としてこの試験法がその後汎用的に 導入された経緯がある。

しかし, 意外にもこの試験法は導入に先立ち, 事前調査 確認が不十分な点が指摘されており, 当学会内に専門の調 查研究会を設置 (主査: 津久井 勤) し, 試験の妥当性を 調查検討されてきた。本報ではこの結果の要約と, 昨年 12 月に開催された公開研究会の参加者からのアンケート (HAST 試験法, 現状抱えている問題点, 実際に携わって いる方の意識など）結果を中心に述べる。

\section{HAST 導入経過}

HAST を含む加圧水蒸気試験の最初の導入は，1960年代 にR.C.A.社におけるソリッド抵抗器の試験であると言われ ている1)。その後, 図1に示すように, 当初は加圧水蒸気 により半導体デバイスへの水分の浸透性を高め, アルミ配 線の腐食性を短期間で評価するために導入された。

しかし, 近年では電子絶縁材料特性のグレードが上がり, 温湿度定常試験（ $85^{\circ} \mathrm{C} 85 \% \mathrm{RH}$ など）では, 故障に至る前 の時間が数千時間以上かかり ${ }^{2)}$, 製品開発に支障を来たす ので, 打開策として, この試験が電子機器全般に至るまで の幅広い分野で普及されてきた。

当初は飽和加圧水蒸気試験 (PCT: Pressure Cooker Test) が 主流であったが, 結露の影響, 市場故障の再現性などの問 題により ${ }^{33,4)}$, HAST が開発され, 今日に至っては広く使わ れるようになった。

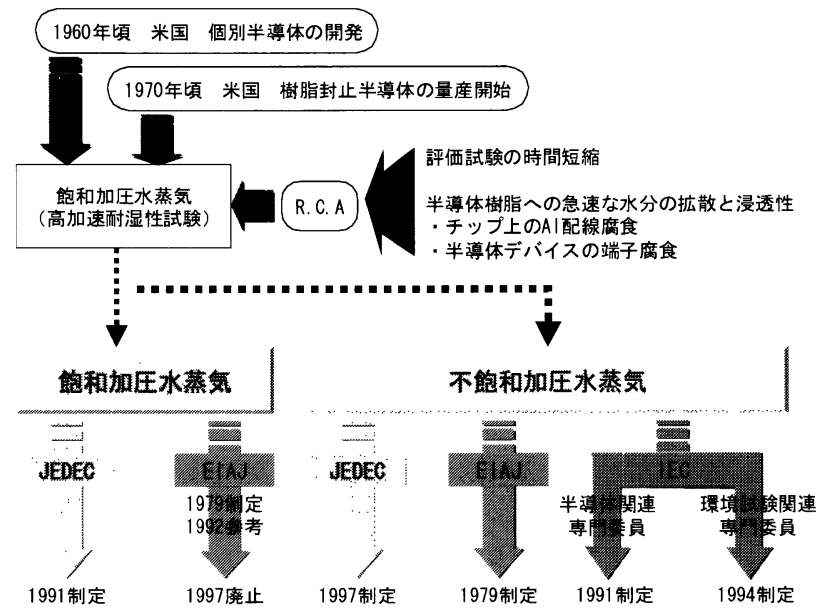

図1. 加圧水蒸気試験法制定の経過

なお，PCTは上記問題点などにより，EIAJ（現JEITA） では1997年に廃止され，現在ではJEDEC のみの規定となっ ているが, 飽和加圧水蒸気による腐食性, 樹脂接合間の密 着性などの評価に優れていることから，今なお半導体デバ イスを中心に使われている。しかし, 後で示す図3のよう に, PCT 条件について 3 章で述べるアンケートを調査した 結果, 湿度 100\%RHに対し, 実際は95 100\%RH の範囲で 試験されており，メーカにより湿度設定条件が異なってい ることがわかった。これは, 環境試験装置の槽内の雾囲気 が, 飽和タイプと不飽和タイプの 2 種類の雾囲気が存在し ていることになる。そのため，今後はPCTにおいて，これ ら湿度の影響を改めて検討する必要がある。

なお, HAST は耐湿性試験法以外にも，信頼性評価の分 野では, 高加速度ストレス試験全般(HAST: Highly Accelerated Stress Test)を意味する場合むあるので，留意されたい。

\section{3. アンケート調査から見たHASTの実態について}

実際にHASTに携わっている技術者が，どのような意識 を持ち，またどのような問題点を抱えているのかなどを明 らかにするために，昨年 12 月に開催した加速寿命試験法 検討研究会の公開研究会の参加者にアンケート調査を行っ 


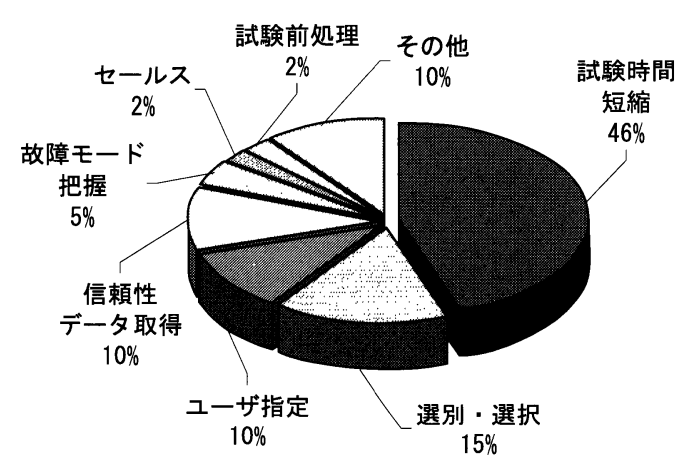

(a) HASTの目的

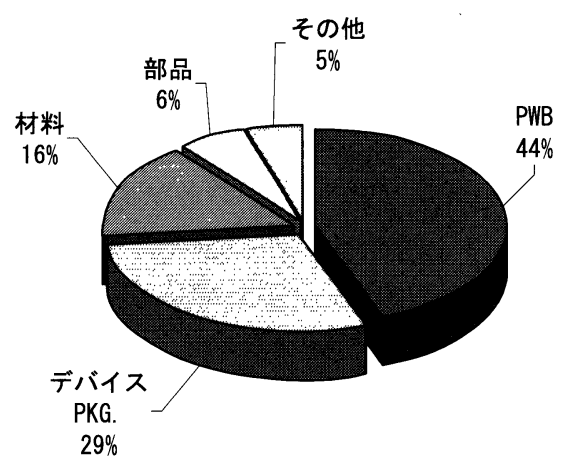

(c)HASTの対象試料

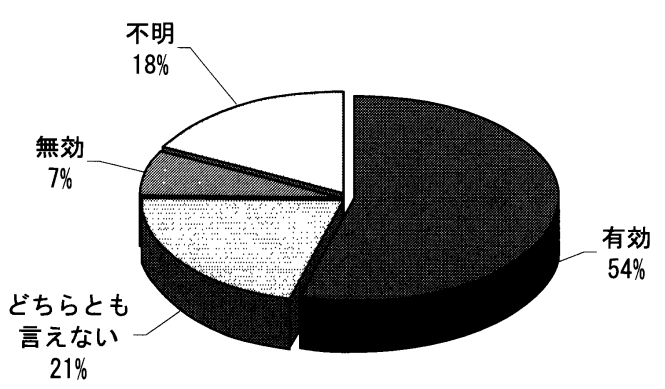

(e)HASTの有効性

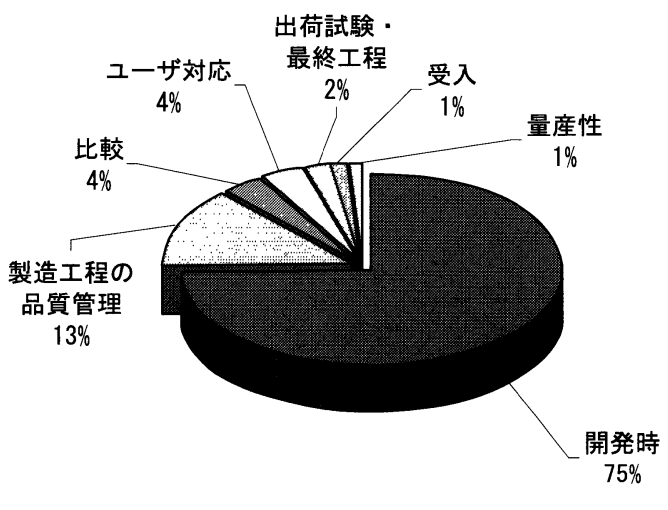

(b) HASTの導入工程

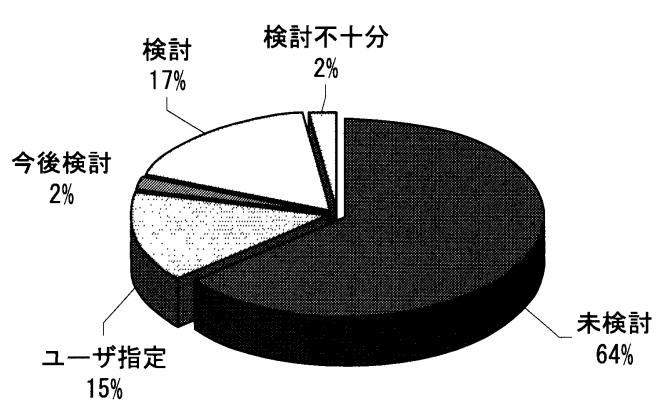

（d）条件選定に当たっての検討

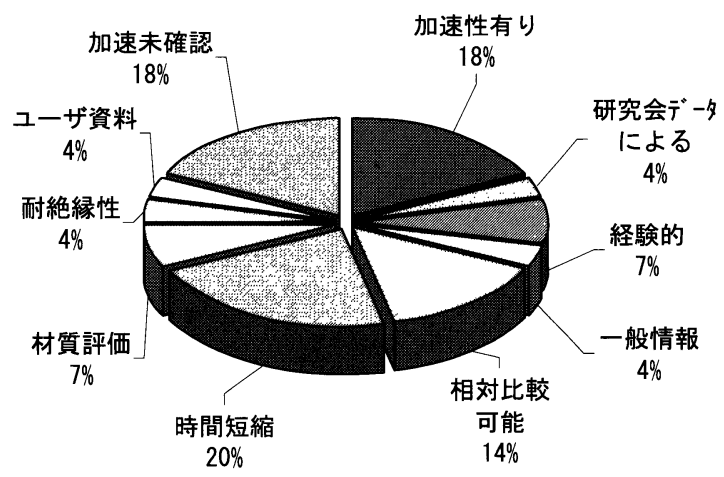

(f) 有効性があると答えた中の内訳

図 2. HASTに関するアンケート調査結果（その1）

た。主な内容を以下に報告する。

今回のアンケート回答率は出席者（110名）のうち約 $60 \%$ で，業種別にみると, 機器, 部品メ一カが全体の約 8 割近く占めている。また, 部門別では研究開発部門が約 6 割で, 設計開発時におけるHAST の利用に当たって, 特に 高い関心が持たれていると言える。

アンケート結果を図 2,3 に示したが，以下に主な概要に ついてまとめた。

(1) HAST の導入目的は, 約 $50 \%$ が試験時間の短縮と相
対評価であり，製品開発の早期立ち上げが前提にある と考える。また, 対象となる試料は, プリント配線板, デバイス PKGが主流であった（図 2 (a)～(c))。

(2) HAST 導入に当たり, 事前検討（条件選定，故障メ カニズム，モードなど）がほとんど実施されておらず， ユーザからの指定とか, 何となく導入されているなど の場合が多い（図 $2(d)) 。$

(3) HASTの有効性は, 回答の約 5 割はあるとのことだ が，そのうち約 4 割は根拠が明確ではなく, 感覚的に 


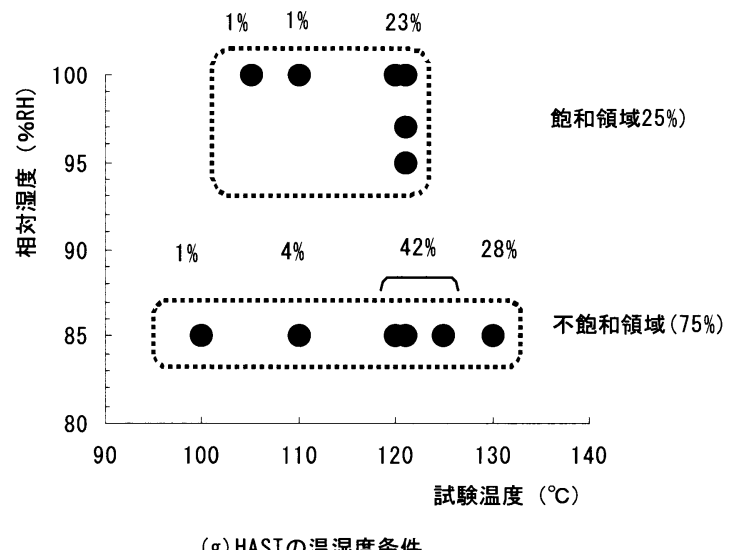

(g) HASTの温湿度条件

図3. HASTに関するアンケート調査結果（その2）

判断されている状況が伺える（図2(e), (f))。

(4) 試験条件は, HAST で $130^{\circ} \mathrm{C} / 85 \% \mathrm{RH}, 120^{\circ} \mathrm{C} / 85 \% \mathrm{RH}$

の順に多く, PCTで, $121^{\circ} \mathrm{C} / 100 \% \mathrm{RH}$ がほとんどであ

る(図 $3(\mathrm{~g}))$ 。

以上のことより, HAST は十分検討した上で導入されて いるのではなく, ほとんどは感覚的な判断であり, ユーザ からの要求に仕方なく導入しているケースが多いようにも 判断される。そのため, この試験法についての妥当性を見 極める検討を必要とされていることを示している。

\section{HASTを実施するに当たってのチェックポイント}

\section{1 関連規格と試験条件について}

主なHAST 規格を表 1 に示す。ほとんどは半導体デバイ 不等部品の適用規格である。一般にはJEDEC 規格が多く使 われている。最近では 2001 年に部品を対象とした日本工業 規格(JIS)が，引き続いてプリント配線板を対象に日本プリ ント回路工業会 (JPCA) がHAST 規格を制定している。また, 一部産業会のロードマップでも HAST は取り上げられてい
$ろ^{5)}$ 。

現在, 一般に規格化されているHAST の温湿度条件は, 温度が $110^{\circ} \mathrm{C}$ と $130^{\circ} \mathrm{C}$ の 2 条件, 湿度が $85 \% \mathrm{RH}$ の 1 条件で ある。HAST の採用に当たっては, 樹脂材料ではガラス転 移温度を超える試験温度では, 故障メカニズムが通常とは 異なる可能性があり, その温度以上では使用しないことが 指摘されている。また, 試験電圧值は, 一般には個別規格 で規定されているが，JPCA 規格の場合は，DC 5 Vから $100 \mathrm{~V}$ の範囲と定めている。参考として, 相対比較の場合 には，比較的高い電圧值（約 DC $30 \mathrm{~V}$ から $100 \mathrm{~V}$ ) で, 製品 の信頼性評価の場合は, 実際に回路上の電源電圧值で設定 する場合が多い。試験条件の設定に当たっては, 絶縁樹脂 材料の場合, 硬化プロセスの影響が顕著に現れるので, 故 障モードが通常とは異なる恐れのないところで, 試験目的, 材料特性, 試料の状態などに応じた条件を設定するのが望 ましい。

最近のパーソナルコンピュータのデバイス動作電圧は, 現在約 DC $5 \mathrm{~V}$ から $1.5 \mathrm{~V}$ と低くなる傾向にあり, イオンマ イグレーションの発生は抑えられるようには思われる。し かしながら, 高密度実装に伴って, ファインピッチ化し, 逆に電界強度は高くなってきているので, 今後とも留意は 必要である。

\section{2 環境試験装置について}

一般にHAST装置には, 図4 に示すように一槽式（空調 方式）上二槽式の 2 タイプがある6)。一槽式は, 水蒸気発 生槽と試験槽が一体となっており, 水蒸気が加熱ヒ一タで 再加熱されファンによりかくはんされるタイプである。二 槽式は, 水蒸気発生槽之試験槽が独立しており, 別の槽で 造られた加湿雾囲気を試験槽へ送るタイプである。

そこで, 前記研究会において両装置の比較試験を行った 結果, 同一試料で両者における故障時間の差異は特に見ら

表 1. HAST 規格一覧表

\begin{tabular}{|c|c|c|c|c|c|c|}
\hline \multirow{2}{*}{$\begin{array}{l}\text { 規格制定 } \\
\text { 団体名称 }\end{array}$} & \multirow{2}{*}{ 規格 No. } & \multirow{2}{*}{ 規格名称 } & \multicolumn{2}{|r|}{ 試 } & \multicolumn{2}{|c|}{ 験 条 件 } \\
\hline & & & $\begin{array}{c}\text { 温度 } \\
\left({ }^{\circ} \mathrm{C}\right)\end{array}$ & $\begin{array}{c}\text { 湿度 } \\
(\% \mathrm{RH})\end{array}$ & 試験電圧 & 試験時間 (h) \\
\hline IEC & $\begin{array}{l}60068-2-66 \\
60749\end{array}$ & $\begin{array}{l}\text { Dump heat,steady state } \\
\text { (unsaturated pressurized vapour) }\end{array}$ & $\begin{array}{l}110 \pm 2 \\
120 \pm 2 \\
130 \pm 2\end{array}$ & $\begin{array}{l}85 \pm 5 \\
85 \pm 5 \\
85 \pm 5\end{array}$ & 任意 & $\begin{aligned} 96,192,408 \\
48,96,192 \\
24,48,96,\end{aligned}$ \\
\hline JEITA & $\begin{array}{l}\text { EIAJ ED4701/100 } \\
102\end{array}$ & 高温高湿バイアス試験 & $\begin{array}{l}110 \pm 2 \\
120 \pm 2 \\
130 \pm 2\end{array}$ & $\begin{array}{l}85 \pm 5 \\
85 \pm 5 \\
85 \pm 5\end{array}$ & $\begin{array}{l}\text { 連続印加 } \\
\text { 断続印加 }\end{array}$ & 個別規定 \\
\hline JEDEC & JESD22-A110 & $\begin{array}{l}\text { Highly Accelerated Temperature } \\
\text { and Humidity Stress Test (HAST) }\end{array}$ & $\begin{array}{l}110 \pm 2 \\
130 \pm 2\end{array}$ & $\begin{array}{l}85 \pm 5 \\
85 \pm 5\end{array}$ & $\begin{array}{l}\text { 連続印加 } \\
\text { 断続印加 }\end{array}$ & 96 \\
\hline JIS & JIS C 0096-2001 & $\begin{array}{l}\text { 高温高湿定常 } \\
\text { (不飽和加圧水蒸気) }\end{array}$ & $\begin{array}{l}110 \pm 2 \\
120 \pm 2 \\
130 \pm 2\end{array}$ & $\begin{array}{l}85 \pm 5 \\
85 \pm 5 \\
85 \pm 5\end{array}$ & 任意 & $\begin{aligned} 96,192,408 \\
48,96,192 \\
24,48,96\end{aligned}$ \\
\hline JPCA & JPCA-ET08-2002 & $\begin{array}{l}\text { 高温・高湿・定常 } \\
\text { (不飽和加圧水蒸気) 試験 }\end{array}$ & $\begin{array}{l}110 \pm 2 \\
120 \pm 2 \\
130 \pm 2\end{array}$ & $\begin{array}{l}85 \pm 5 \\
85 \pm 5 \\
85 \pm 5\end{array}$ & $\begin{array}{c}\text { 任意 } \\
\text { DC 5 } \\
100 \mathrm{~V}\end{array}$ & $\begin{aligned} 96,192,408 \\
48,96,192 \\
24,48,96\end{aligned}$ \\
\hline
\end{tabular}




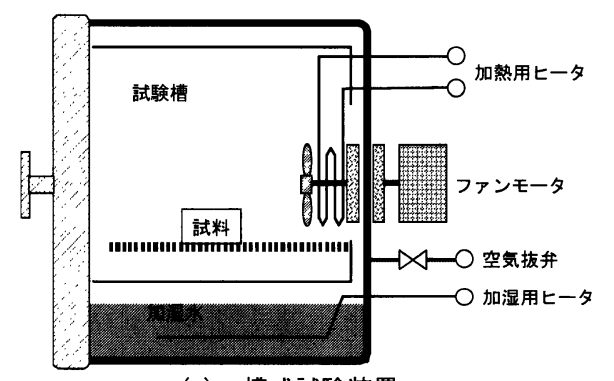

(a) 一槽式試験装置

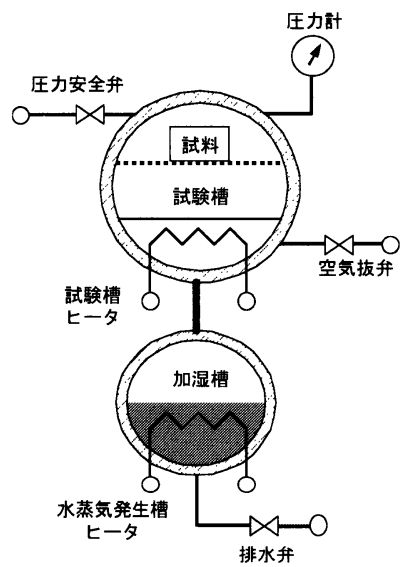

(b) 二槽式試験装置

図 4. HAST 装置の構造

れなかったと報告されている7)。

なお，留意事項として，環境試験装置の制御している温 湿度は, 実際に試料設置場所とは異なるので, 試料周辺部 の温湿度は事前に確認しておくことが指摘されている。

以下に国内における HAST 装置の主な仕様を示す。

$$
\begin{array}{lc}
\text { 温度 } & 105 \sim 160^{\circ} \mathrm{C} \\
\text { 湿度 } & 65 \sim 100 \% \mathrm{RH} \\
\text { 圧力 } & 0.02 \sim 0.40 \mathrm{MPa}
\end{array}
$$

参考までに, 米国製の試験装置には, 圧力が約 $0.6 \mathrm{MPa}$ と非常に高い領域まで使用できるものがある。これは, 高 ガラス転移温度（約 $150^{\circ} \mathrm{C}$ 以上）の樹脂封止パッケージな どの評価に使用されているようである。

\section{3 計測システムについて}

耐湿性試験における絶縁劣化の計測方法は，試料を環境 試験装置より取り出して計測する方法（スタティック測定） と, 試料を環境試験装置に入れた状態で計測する方法（ダ イナミック测定）がある ${ }^{8)}$ 。後者の方法は, 電圧印加中に イオンマイグレーションで短絡した場合に検出可能な利点 があり，現在一般的に多く使われている方法である。また， この方法は, 簡易的な回路で電圧をモニターする電圧降下 法と, リーク電流を連続的にモニタ一する方法とがあり, いずれも長所短所があり, 試験精度, 評価コストなどを考 慮し選択する方が良い。

絶縁抵抗值の判定基準は個別規格によるが，一般的には JPCA 規格で規定されているように，スタティック測定で $10^{7} \Omega$ 以上，ダイナミック測定で $10^{6} \Omega$ 以上が一般的である。 特にHAST の絶縁劣化計測で留意する点は, 判定抵抗值 が試料の絶縁抵抗值の他, 環境試験装置（内部引き回し配 線抵抗, 接続端子など）や, 計測部を含めた抵抗值が加算 されるので，試料の絶縁抵抗值より十分低くするとともに, 誘導ノイズが入らないようにすることが必要である。また， 試料の導体間隙が狭い場合や, 材料系によっては, 加湿段 階ですでに判定抵抗值まで擬似的に降下する場合があり, 劣化判定值と試験条件の設定には事前に検討しておく必要

\begin{tabular}{|c|c|}
\hline 加速ストレス & 加速モデル式 \\
\hline 温 度 & $\mathrm{L}=\mathrm{A} \cdot \exp (\mathrm{Ea} / \mathrm{kT})$ \\
\hline 湿 度 & $\mathrm{L}=\mathrm{A} \cdot(\mathrm{RH})^{-\mathrm{n}}$ \\
\hline 電 圧 & $\mathrm{L}=\mathrm{A} \cdot \mathrm{V}^{-\mathrm{n}}$ \\
\hline \multicolumn{2}{|l|}{ （備考） } \\
\hline L：寿命 & Ea：見かけ上の活性化エネルギ \\
\hline $\mathrm{T}$ ：絶対温度 & $\mathrm{RH}$ ：相対湿度 $\mathrm{V}$ ：電圧 \\
\hline k ：ボルツマン定数 & $\mathrm{A}, \mathrm{n}$ : 定数 \\
\hline
\end{tabular}
がある（特にプリント配線板の場合には，加湿前より加湿
表 2. 耐湿性評価の加速モデル

後で絶縁抵抗値が 3 桁以上低下する場合がある)。

\section{5. 耐湿性評価試験の加速モデルについて}

一般にHAST を含めた耐湿性評価試験では, 温度, 湿 度, 電圧 (電界強度), 水蒸気圧などのストレス因子に対 する加速モデルがある。一般的によく使われている加速モ デルを表 $2 に$ 示す。これは, 加速寿命試験法検討研究会の プリント配線板におけるHAST の加速性評価に使われた加 速モデルで, 温度の加速性はアレニウスモデルで, 湿度と 電圧の加速性は, それぞれ湿度, 電圧ストレスのベキ乗則 の加速モデルである。各加速モデルは, 寿命に対してある 程度の加速性が認められている。

ただし，加速モデルが成立つには，フィールド条件と加 速ストレス条件において, 故障モードと故障メカニズムが 同じであることが前提である。

\section{HAST の評価状況について}

HAST の評価事例は，ほとんどが樹脂封止半導体デバイ ス（ICパッケージ）に関するもので，プリント配線板など は過去において報告された事例が少ない。以下にHASTの 評価事例として樹脂封止半導体デバイスと, 前記研究会で 実施されたプリント配線板の評価事例について報告する。

6.1 樹脂封止半導体デバイスの評価事例について

樹脂封止半導体デバイスの HAST 結果については, 過去 に数多くのデー夕を体系的にまとめたものがあるので図 5 


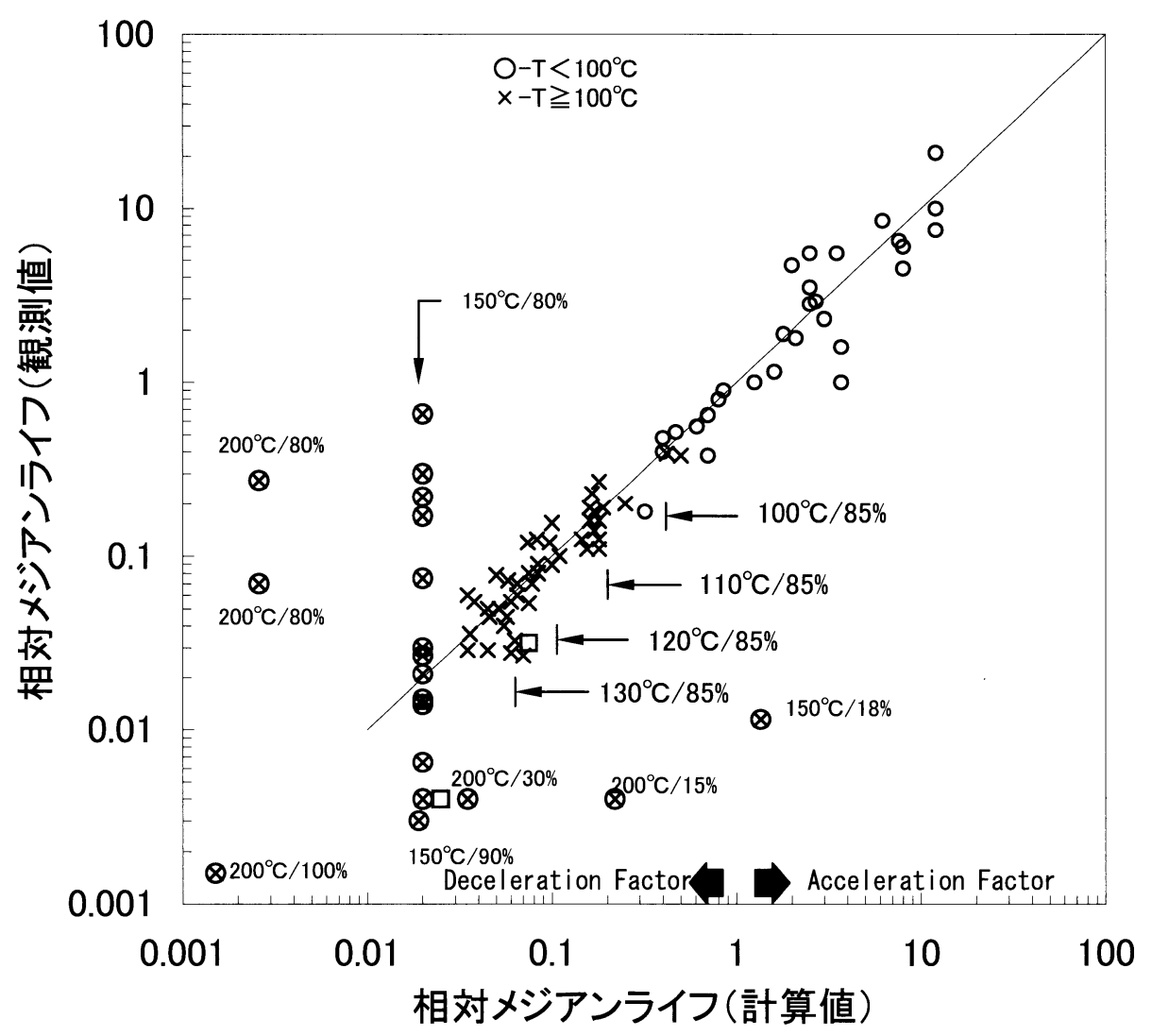

図 5. $85^{\circ} \mathrm{C} 85 \% \mathrm{RH}$ に対する観測データと計算データと相関寿命

に紹介する9)。これは，エポキシ樹脂で封止されたパッケー ジのアルミ配線の腐食性を見たもので, 試験デー夕による 故障時間と，アレニウスモデルにより計算した故障時間を， それぞれ $85^{\circ} \mathrm{C} 85 \% \mathrm{RH}$ の故障時間を1としてプロットした ものである。この図で, 特に $150^{\circ} \mathrm{C}$ の温度条件（凤印の個 所）では故障時間のばらつきが大きい。また，ガラス転移 温度が $145^{\circ} \mathrm{C}$ のポキシ樹脂について, 試験温度 $130^{\circ} \mathrm{C}$ と $150^{\circ} \mathrm{C}$ で評価した結果（口印個所）， $130^{\circ} \mathrm{C}$ 以下の傾向と $150^{\circ} \mathrm{C}$ 以上の傾向に大きな違いが見受けられることから， エポキシの封止樹脂のガラス転移温度となんらかの関連性 があると指摘している。

\section{2 プリント配線板の評価事例について}

前述のように，当初はプリント配線板で HAST は実施さ れていなかったが, 半導体デバイス評価に影響されて, 頻 繁に導入されるようになった。しかしながら，プリント配 線板関連の HAST の事例については，以前から公開された デー夕が非常に少ないのが現状である。そこで, 当学会で は前記研究会を設置し, プリント配線板について, 材料の グレード別に体系的な評価が行われた。以下に研究会で実 施された事例をもとに概要を報告する7)。

この評価は，ガラスクロス強化基材にソルダレジストを 塗布した単純な構造の NEMA グレードに基づいた櫛形基板 でHASTを行ったものである。HAST 条件は $110^{\circ} \mathrm{C} 85 \% \mathrm{RH}$, $130^{\circ} \mathrm{C} 85 \% \mathrm{RH}$ の 2 条件と, $85^{\circ} \mathrm{C} 85 \% \mathrm{RH}$ の低加速条件の計 3 条件について評価された。その結果, 表 3 に示すように
表 3. プリント配線板 (FR-4)の HASTにおける加速係数

\begin{tabular}{c|r|r|c|r}
\hline 試料内訳 & 試験温度 & MTTF & 見かけ上の活性化エネルギ & 加速係数 \\
\hline \multirow{3}{*}{ FR-4 試料 1} & $130^{\circ} \mathrm{C}$ & $38 \mathrm{~h}$ & & \\
& $110^{\circ} \mathrm{C}$ & $490 \mathrm{~h}$ & $1.70 \mathrm{eV}$ & 470.9 \\
& $85^{\circ} \mathrm{C}$ & $17892 \mathrm{~h}$ & & 36.5 \\
& $130^{\circ} \mathrm{C}$ & $112 \mathrm{~h}$ & & 1.0 \\
\hline \multirow{3}{*}{ FR-4 試料 2} & $110^{\circ} \mathrm{C}$ & $920 \mathrm{~h}$ & $1.40 \mathrm{eV}$ & 159.0 \\
& $85^{\circ} \mathrm{C}$ & $17811 \mathrm{~h}$ & & 19.4 \\
& $130^{\circ} \mathrm{C}$ & $25 \mathrm{~h}$ & & 1.0 \\
\hline \multirow{3}{*}{ FR-4 試料3 } & $110^{\circ} \mathrm{C}$ & $326 \mathrm{~h}$ & $1.71 \mathrm{eV}$ & 483.8 \\
& $85^{\circ} \mathrm{C}$ & $12095 \mathrm{~h}$ & & 37.1 \\
& \multicolumn{3}{|c}{} \\
\hline
\end{tabular}

加速モデルは，アレニウスモデルを用いて解析されており， 同一試料では, 見かけ上の活性化エネルギは一定で, 加速 性が得られる結果となった。 $85^{\circ} \mathrm{C}$ を基準として高温度側 $130^{\circ} \mathrm{C}$ における加速係数の FR-4 基板で基板メ一カの違いで 差が見られたため, 約 160 490 倍と幅のある結果になって いる。このように同じグレード内でも基板メーカの違いに よりかなりの違いがあることを示している。現在, 低温度 側 $\left(85^{\circ} \mathrm{C} 85 \% \mathrm{RH}\right)$ での試験が継続されており, この結果が出 るとHAST の有効性についてさらに明確になると予想され る。

なお，プリント配線板では，加湿時の飽和時間（吸湿特 性）之材料の加水分解との関連性が指摘されており, 故障 判定時間の設定は，その時間を目安に設定すべきとの見解 あある ${ }^{10)}$ 。ただし, 重量を測定する場合, 試料の加湿終了 
時の泠却方法（急冷と徐冷）により重量值が異なるので, どの方法を選択するかは検討を要する11)。

\section{HAST試験槽の取り扱いに関する留意点について}

HAST は非常に加速性が高いことが影響し、コンディ ションの維持管理が難しい試験とも言える。そこで, HAST 特有と屯言える主な環境試験装置取り扱い上の問題点之留 意点を以下にまとめた。

(1) 電子部品に使用されている樹脂の硬化状態により故 障時間 (寿命) が異なるので, 試料作成時のプロセス には十分な注意が必要である ${ }^{12)}$

(2) 環境試験装置の耐用年数, 環境試験装置の槽内の污 染状態, 使用水の水質などにより, 試料間での故障時 間, 試験所間での故障時間が異なる結果をもたらす要 因之なるので，事前の確認が必要である7。

(3) 環境試験装置内の残留空気（酸素濃度など）の影響 で，プリント配線板などの樹脂材料の硬化が促進（基 板の色調に変化) され77,13), 異なる故障モードが見ら れるので, 環境試験装置取り扱いについてきめ細かい 規定が必要である。

(4) 環境試験装置, 試料からアウトガスが発生する。こ れは, 試験装置槽内の材質, 試料数, 試験時間, 試験 温度, 材料のガラス転移温度などの違いによって異な るが14), 試験への影響が懸念されている。そのため, 槽内の洗浄などによってアウトガスの発生を抑えるこ とが必要である。

\section{8. おわりに}

将来における信頼性評価の理想像は, 現状の試験に頼る 評価ではなく, 設計段階での信頼度予測（机上での予測） に基づく評価と考えられる。そのためにHAST はその到達 点に近つくために不可欠な手法であり, 現状も含め将来に おける開発スタンスに非常に合致した寿命加速試験法と考 える。しかし, その試験の有効性についてはいまだに賛否 両論があり, 特に電子絶縁材料では, 評価デー夕と故障物 理的な側面からの解析が不十分であり結論が出るまでには 至っていない状況である。現状 HAST は, プレコンディ ションの吸湿工程として, またCAFの評洒試験としても導 入されている。

今後は多様化するニーズと使用環境の変化により標準化 が難しくなりつつある中で, 柔軟性のある評価技術の確立 が必要とされ, 加速寿命試験法とはどうあるべきかを問わ れる時期が来ていると考える。

なお, 当学会の加速寿命試験法検討研究会にて, プリン 卜配線板におけるHAST研究ができたことは, 今後の信頼 性評価のあり方に一石を投じたものであり, 各委員に深謝 する。

(2003.8.13-受理)

\section{文献}

1) 三根 久 (編) : “プレッシャー・クッカー・テストに関す る文献調查報告書”, 関西電子工業振興センター, 1983

2) J. E. Gunn and S. K. Malik: "Highly Accelerated Temperature and Humidity Stress Test Technique (HAST)", 19th Annual Proceedings Reliability Physics, pp. 48-51, 1981

3) 户井恵子, 山本敏男, 吉田弘之: “プレッシャークッカー 試験実施上の問題点 (1)”, 第 16 回日科技連信頼性 - 保全性 シンポジウム, pp. 405-408, 1986

4) 余田浩好, 戸井恵子, 山本敏男, 吉田弘之: “プレッ シャークッカー試験実施上の問題点 (2)”, 第 17 回日科技連 信頼性・保全性シンポジウム, pp. 179-184, 1987

5) “2001年度版日本実装技術ロードマップ”, JEITA（社団法 人電子情報技術産業協会)，2001

6) 高久 清, 他 : “デバイス・部品の信頼性試験”, 信頼性 110 番シリーズ第 2 卷, 日科技連出版社, 1999

7) “HASTによる加速劣化試験結果とその課題”, エレクトロ ニクス実装学会, 加速寿命試験法検討研究会, 2002

8）JPCA-ET01-2002, “プリント配線板環境試験方法－通則 (2001の改訂版)”, 日本プリント回路工業会, 2002

9) D. S. Peck: "Comprehensive Model for Humidity Testing Correlation", 24th Annual Proceedings Reliability Physics, pp. 44-50, 1986

10) 中村和裕, 津久井 勤：“HASTによるプリント配線板の而的 湿性評価について”, 第 12 回マイクロエレクトロニクスシ ンポジウム(MES2002) 論文集, pp. 339-402, 2002

11）細谷長貞, 山市 隆：“電子部品の信頼性のためのプレッ シャークッカ適用の一考察 (その1)”, 第 18 回日科技連信 頼性・保全性シンポジウム, pp. 233-238, 1988

12) 中村和裕：“プリント配線板の耐湿性評価における加速試 験法の課題”, 第 16 回エレクトロニクス実装学術講演大会 講演論文集, pp. 119-120, 2002

13) K. Toi, H. Yoshida, T. Yamamoto and M. Yamauchi: "HAST (Highly Accelerated Temperature \& Humidity Stress Test) under Air and Steam", 22th Symposium on Reliability and Maintainability, pp. 130-135, 1992

14) 川由信行, 他：“蒸気污染がプレッシャ・クッカ試験に及 ぼす影響”, 第 19 回日科技連信頼性・保全性シンポジウム, pp. 291-296, 1989

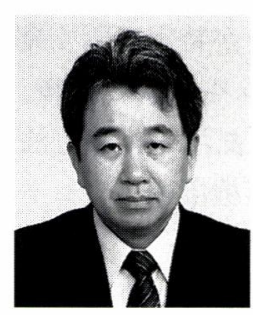

中村 和裕（なかむら かずひろ）

昭和 33 年生まれ。昭和 57 年, 千葉工業大学電気 工学科卒業。現在, 新光電気工業株式会社基盤 技術研究所勤務。電子部品の加速劣化試験法に おける信頼性評価技術の研究開発に従事。 